\title{
Sustainable Operations Management: An Enduring Stream or a Passing Fancy?
}

\section{Citation}

Drake, David, and Stefan Spinler. "Sustainable Operations Management: An Enduring Stream or a Passing Fancy?" Special Issue on the Environment. Manufacturing \& Service Operations Management 15, no. 4 (Fall 2013).

\section{Published Version}

http://pubsonline.informs.org/doi/pdf/10.1287/msom.2013.0456

\section{Permanent link}

http://nrs.harvard.edu/urn-3:HUL.InstRepos:28538425

\section{Terms of Use}

This article was downloaded from Harvard University's DASH repository, and is made available under the terms and conditions applicable to Open Access Policy Articles, as set forth at http:// nrs.harvard.edu/urn-3:HUL.InstRepos:dash.current.terms-of-use\#OAP

\section{Share Your Story}

The Harvard community has made this article openly available.

Please share how this access benefits you. Submit a story.

Accessibility 


\title{
Sustainable Operations Management: An enduring stream or a passing fancy?
}

\author{
David F. Drake \\ Harvard Business School, Harvard University, Boston, MA 02163, U.S.A. \\ ddrake@hbs.edu \\ Stefan Spinler \\ WHU - Otto Beisheim School of Management, 56179 Vallendar, Germany \\ stefan.spinler@whu.edu
}

\begin{abstract}
Paul Kleindorfer was among the first to weigh in on and nurture the stream of Sustainable Operations Management. The thoughts laid out here are based on conversations we had with Paul relating to the drivers underlying sustainability as a management issue: population and per capita consumption growth, the limited nature of resources and sinks, and the responsibility and exposure of firms to ensuing ecological risks and costs. We then discuss how an operations management lens contributes to the issue, and criteria to help the Sustainable Operations Management perspective endure. This article relates to a presentation delivered by Morris Cohen for Paul's Manufacturing and Service Operations Management Distinguished Fellows Award, given at Columbia University, June 18, 2012. We wrote this article at Paul's request.
\end{abstract}

Key words: Sustainable operations management; Sustainability; Environment; Paul Kleindorfer

History: Submitted March 29, 2013; revised June 22, 2013; revised June 29, 2013

Paul Kleindorfer was a pioneering and impactful force in the field of Sustainable Operations Management (Sustainable OM). He was among the first to lend his voice to the field (Kunreuther and Kleindorfer 1980), co-edit a number of the original special issues on the subject (Corbett and Kleindorfer 2001a, Corbett and Kleindorfer 2001b, and Corbett and Kleindorfer 2003), and coauthor a survey of its early work (Kleindorfer et al. 2005). As two of Paul's former students, we were among the many fortunate enough to benefit from his vast knowledge of the subject and his generosity in sharing it.

The recent burgeoning of Sustainable OM was a point of pride for Paul. But, forever the mentor, he would not allow us to merely observe and contribute to its growth. He pushed us to question the stream's ability to endure. It matters relatively little that the field is of interest today, he would say. When you look back over your career 20 years from now, will Sustainable OM prove to have been an enduring stream or a passing fancy? That question invariably led to two others: 1) Why is sustainability, broadly speaking, of growing interest?; and 2) What does the field of operations management $(\mathrm{OM})$ have to contribute to it? 


\section{Why is Sustainability of Growing Interest?}

The finite and semirenewable nature of many global resources and the limited ability of ecosystems to absorb pollutants have long been recognized ${ }^{1}$. However, because the renewable supply of these resources (e.g., water, forests, fish stocks) or the rate at which new sources were discovered (e.g., minerals, oil) vastly exceeded their consumption, their limited nature was not historically perceived to be a binding constraint for the development of production systems to fuel economic growth. The future in which these natural assets might become limiting resources seemed distant, left largely to dystopian visions in film and literature. However, that future is now in sight. Two fundamental factors have thrown these constraints into relief: population growth and increasing per capita consumption.

Thomas Malthus (1798) argued that population growth threatens economic sustainability, observing that population grew "in a geometrical ratio" (i.e., exponentially) while food production, in Malthus' estimation, grew "in an arithmetical ratio" (i.e., linearly). While his theory has drawn criticism, Malthus receives credit for originating the discussion on economic sustainability and identifying population growth as one of its principal challenges. That growth has not abated. Worldwide population grew to 6.97 billion by 2011, an increase of $83 \%$ since 1970, with the vast majority of that growth occurring in emerging economies (Global Financial Data 2013). The United Nations estimates that this growth will continue, albeit at a decreasing rate, reaching a global population of 9.31 billion by 2050 and over 10 billion by 2100 (UN, Department of Economic and Social Affairs, Population Division 2011).

Similarly, since 1970, a combination of shorter product life cycles and increased purchasing power has contributed to a $138 \%$ increase in developed economies' per capita consumption while increased earnings and greater access to consumer goods has helped drive a $231 \%$ increase in per capita consumption in emerging economies (World Bank 2013). Together, these trends propel exponential growth in the world's aggregate consumption, with an astounding $671 \%$ increase in consumption in emerging economies. Given that per capita consumption in these regions is still only about $1 / 17^{\text {th }}$ that of the developed world (World Bank 2013), we should expect considerable growth ahead. Figures 1a-c below illustrate each of these trends.

These underlying drivers - particularly population and income growth, and greater access to consumer goods in developing economies - do not seem likely to abate any time soon. With the continuance of these trends, growth in global consumption also projects forward, placing increasing demands on production systems worldwide.

\footnotetext{
${ }^{1}$ As early as 1272, for example, smog in London was so bad that King Edward I banned the burning of sea coal, with violations punishable by torture or death. The ban proved ineffective (Urbanito 1994).
} 

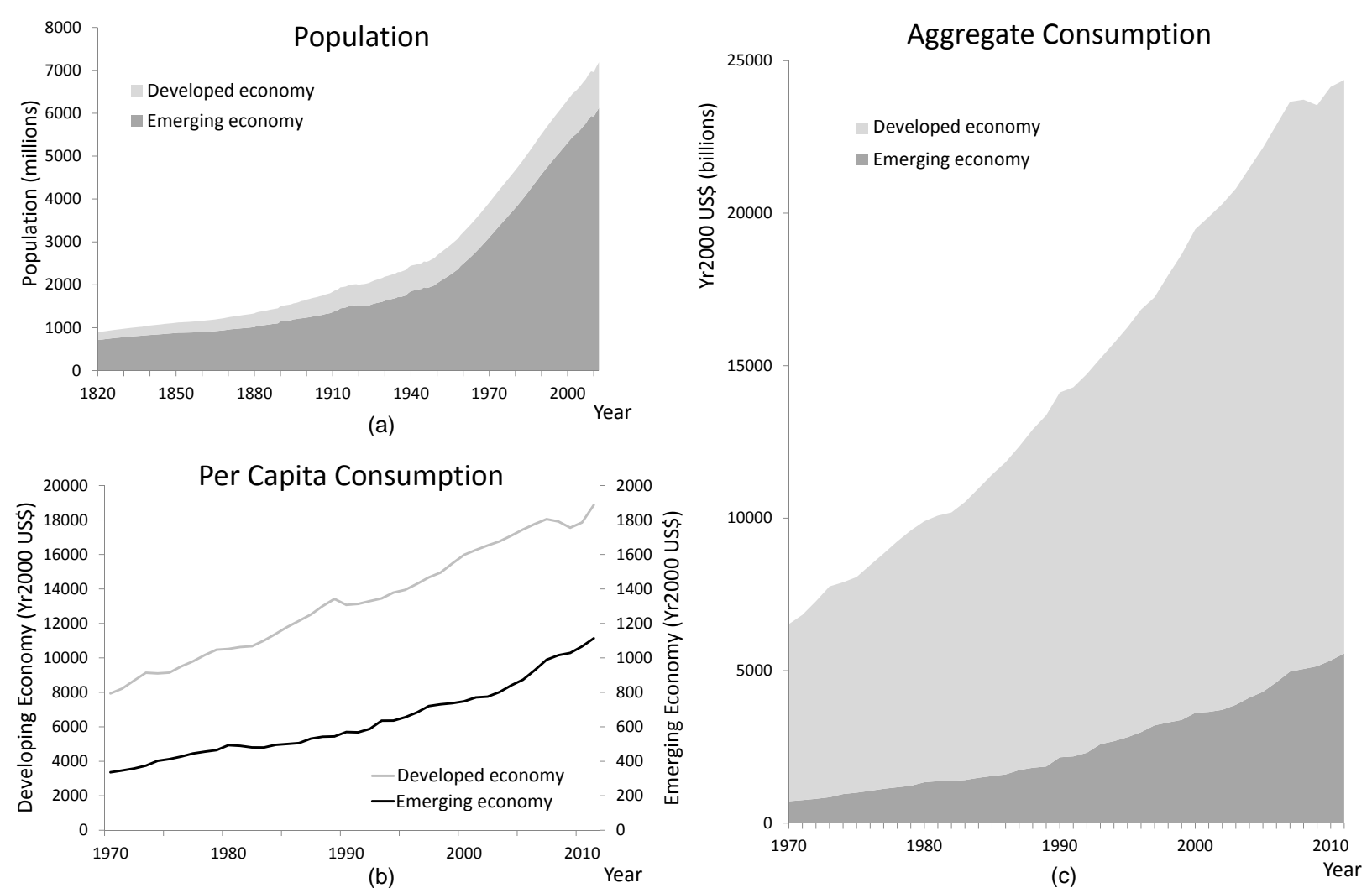

(c)

Figure 1 Trends in population (Figure 1a), per capita consumption (Figure 1b), and aggregate consumption (Figure 1c). Source: World Bank (2013).

In their seminal work, The Limits to Growth, Meadows et al. (1972) refer to growth in consumption and the limited nature of "sources and sinks" - the finite supply of many natural resources and the finite capacity of ecosystems to absorb pollutants without conspicuous effects - as the core challenges to achieving an ecologically sustainable economy. This is not to say that all consumption of sources or emission of pollutants is unsustainable. Technological innovation can improve production efficiency with respect to source and sink use, mitigating certain sustainability concerns. Indeed, it is precisely such innovation that has spared us so far from the population crises predicted by Malthus. Advances in agrarian technology - the invention of iron plows in the 1790s, steel plows and threshing machines in the 1830s, modern irrigation and chemical fertilizers in the 1840s, and so forth - have enabled agricultural output to grow exponentially rather than at the linear rate predicted by Malthus. Even today, as illustrated in Figures 2a-c, agricultural factor efficiency (output per unit of factor input) in the United States continues to improve exponentially, whether the factor considered is land, labor, or a multifactor combination of capital, materials, and labor. Agricultural output has thus managed to keep pace with population growth and hold Malthus' sustainability crisis at bay. 


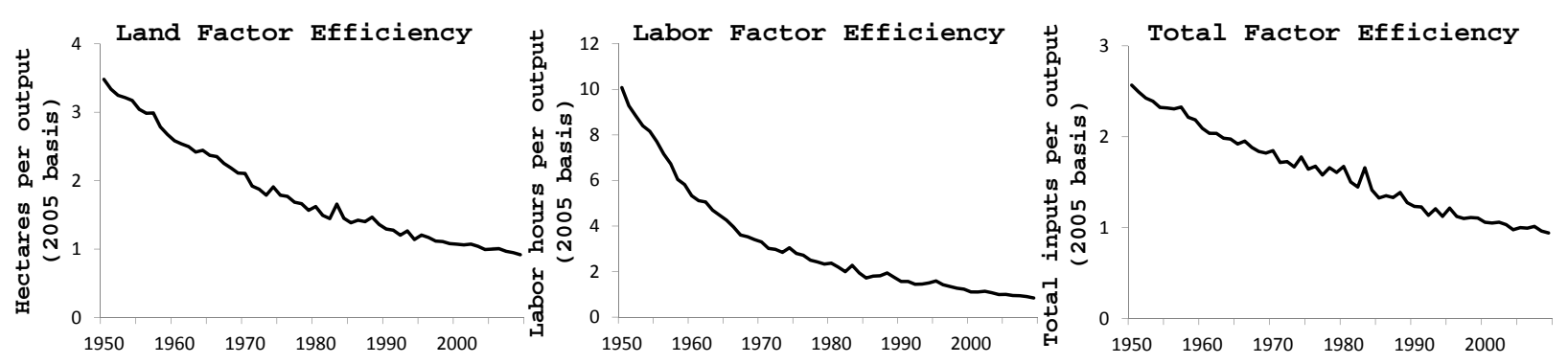

Figure 2 Trends in the agricultural factor efficiency of land (Figure 2a), labor (Figure 2b), and all factors (Figure 2c) relative to a 2005 basis. Source: USDA Economic Research Service (2013)

This discussion relates closely to "IPAT" (Ehrlich and Holdren 1971), which stands for Impact $=$ Population $\mathrm{x}$ Affluence $\mathrm{x}$ Technology, although in the discussion above we substitute per capita consumption for affluence (which is generally measured by per capita GDP). We do so because consumption indicates more directly the demands placed on production systems.

To understand when consumption growth can lead to sustainability concerns that require regulatory action and when those concerns might better be addressed by free-market-induced technological change, one must first consider what levels of activity are sustainable. El Serafy (1989) and Daly (1990) outlined three intuitive sustainability criteria in the form of upper bounds on consumption and pollution rates: (i) Consumption of a renewable source is sustainable if it is no greater than the regeneration rate of that source; (ii) consumption of a nonrenewable source is sustainable if the economy substitutes an alternate material or technology at a sufficient rate that the nonrenewable resource is fully replaced before its reserves are exhausted; and (iii) the emission of pollution (or waste) is sustainable if it occurs at a rate no greater than the rate at which its sink (the ecosystem into which it is injected) can naturally assimilate it plus the rate at which the pollutant is actively removed. Figure 3 summarizes these sustainability criteria.

\begin{tabular}{|l|l|l|}
\hline Resource & Activity & Maximum sustainable rate \\
\hline \multirow{2}{*}{ Source } & $\begin{array}{l}\text { Consumption of } \\
\text { renewable source }\end{array}$ & Rate of source regeneration \\
\cline { 2 - 3 } & $\begin{array}{l}\text { Consumption of } \\
\text { nonrenewable source }\end{array}$ & $\begin{array}{l}\text { Maximum rate that allows for full } \\
\text { substitution before exhaustion }\end{array}$ \\
\hline Sink & Emission of pollutant & Rate of removal and assimilation \\
\hline
\end{tabular}

Figure 3 El Serafy (1989) and Daly (1990) criteria for maximum sustainable consumption and pollution. rates

While these criteria are relatively straightforward to comprehend, adhering to them on a global scale is far from easy. Chief among the challenges are: (i) Uncertainty and debate with respect to 
the various rates which define the criteria; and (ii) the pursuit of local objectives that require the consumption of shared resources. The former makes intervention more difficult (whether that intervention is regulation or a free-market "invisible hand") while the latter contributes to a "tragedy of the commons" on firm and national levels (Hardin 1968, Aflaki 2013). There is growing evidence that, as a result of these challenges, we have already ventured into unsustainable territory on a number of fronts.

Rockström et al. (2009) identify nine "planetary boundaries," building the case that the longterm stability of the biosphere would be at risk should any of these boundaries be violated. The authors find that human activity has already resulted in the violation of three of the thresholds, suggesting that we are operating in the "red zone" with respect to anthropogenic impact. Similarly, Wackernagel et al. (1999) develop a framework to map source and sink consumption to landarea requirements; that is, to an "ecological footprint." They estimate that we would require 1.5 earths to sustain current levels of human activity (footprintnetwork.org 2013). These findings are ultimately driven by an unsustainable rate of consumption of specific sources and an unsustainable rate of emission into specific sinks.

\section{Finite supply of natural resources}

The "overconsumption" of nonrenewable resources is seldom a matter of actually exhausting those resources, but rather a matter of incurring ever-increasing marginal costs. For example, if only the known reserves of copper and silver are considered (i.e., stocks which have been identified and which can be exploited economically), then we have only an estimated 22- and 15-year supply left, respectively (Mining, \& Sustainable Development Project 2002). If, on the other hand, one were to estimate the entire resource base of both minerals (including undiscovered and currently uneconomic sources), then the horizons become 736 and 731 years, respectively (Mining, \& Sustainable Development Project 2002). Further discoveries will be made and new extraction technologies will be developed, so that the actual horizon for both minerals will fall somewhere between these extremes. However, the marginal extraction cost is very likely to increase as we harvest veins less conveniently located in the Earth's crust.

Crude oil is perhaps the most commonly cited nonrenewable resource in this context. Kerr (2011) and Murray and King (2012) indicate that since 2005, oil production has been inelastic to demand while prices have increased by about $15 \%$ per year. From this, they infer that production capacity has a ceiling of about 75 million barrels per day. They go on to argue that neither conventional nor unconventional oil sources (i.e., tar sands) are likely to significantly increase production beyond current levels. While average crude oil prices are expected to be $90-130 \$ /$ bbl by 2020 (US Energy Information Administration 2012), price volatility is likely to increase significantly. Substituting 
natural gas for crude oil may offer a remedy. Indeed, the IEA (2012) touts a golden age of gas fueled by unconventional gas sources such as shale-gas fracturing (fracking). Such substitution-in this case, natural gas for oil-satisfies the Daly criteria for sustainable consumption of finite resources, however it can exacerbate sustainability concerns on other dimensions, as discussed below.

As Simon (1998) argued, when the supply of a finite resource becomes increasingly scarce, traditional supply-and-demand economics lead to a greater market price for the good relative to available extraction technologies and substitutes. This, in turn, incentivizes more exploration and technological innovation to access previously unknown, unobtainable, or uneconomic sources of the good. If supply becomes scarce enough, then the relative price increase incentivizes a transition to alternate resources; e.g., transitioning from oil to natural gas. Such transitions may be disruptive, potentially requiring significant infrastructure investment and/or unsettling established market balance. However, in such a manner, free-market mechanisms can ensure the sustainability of priced resources, either by increasing supply through discovery and extraction or decreasing demand through substitution. Even so, free-market mechanisms are not a universal sustainability panacea.

In the case of crude oil, the extraction of new sources (e.g., tar sands) and the transition to alternative resources (e.g., natural gas) can have unintended sustainability effects. While extraction from tar sands increases the world's oil reserves, it is significantly more emissions-intensive than conventional oil extraction (Lattanzio 2013). Similarly, the spike in natural gas supply from fracking helps alleviate peak oil concerns and provides a lower-emissions-intensity alternative to oil. However, lower natural gas prices could reduce the adoption of zero-emissions energy technologies (e.g., wind, solar, hydro) and suppress investment in energy efficiency improvements. As McKibben (2012) notes, there are 2,795 gigatons of carbon embedded in proven oil, gas, and coal reserves currently owned by fossil fuel firms - nearly five times the carbon that it is estimated would result in a two-degree-Celsius increase in average global temperature (Meinshausen et al. 2009). Therefore, while the discovery of more oil, gas, or coal may alleviate peak oil concerns, it does so at the cost of exacerbating sustainability concerns on other fronts.

Further, free-market mechanisms break down for resources that are not priced. With water consumption more than doubling over the last century (UN Water 2013), it is not difficult to imagine the demand for fresh water outstripping its regeneration rate. Already, half of the developing world's hospital beds are filled by those suffering from water-related diseases (UN Development Programme 2006). Worldwide, such diseases cause nearly $20 \%$ of deaths among children under the age of five (WHO/UNICEF 2009). Given asymmetric access to wealth and the universal need for water, pricing water in such scenarios to bring it within the control of market mechanisms would likely fail to equitably address these water scarcity concerns. 


\section{Finite capacity for ecosystems to absorb pollutants}

As OM scholars, it is natural to think of the sustainability of pollutant emissions into sinks in queuing terms. If the average arrival rate of waste into an ecosystem exceeds the average rate at which that waste can be served by that ecosystem (i.e., removed from or assimilated by it), then waste will accumulate infinitely and that ecosystem is unstable; i.e., the level of emissions being injected into the system is unsustainable. Therefore, evaluating ecosystem stability with respect to waste emissions requires an understanding of a pollutant's arrival rate into the system and the rates at which the pollutant can be removed from and assimilated by the system.

The US Environmental Protection Agency (2011) currently monitors, through the Toxics Release Inventory alone, the emission of over 500 pollutants from nearly 3,000 facilities around the country while Europe, under the European Union Emissions Trading Scheme (often referred to as the EU-ETS), monitors over 11,000 facilities for their greenhouse gas (GHG) emissions (European Commission 2013). This suggests that regulators possess the capability to monitor the arrival of a large number of emissions/pollutants to various ecosystems on a vast scale. The greater challenges generally are estimating the rate at which specific sinks can naturally render those emissions harmless (i.e., assimilate them) and limiting the arrival of emissions into sinks once those maximum sustainable rates are identified. Because the absorptive rate of a sink is not always clear, there is room for both scientific and political debate, which can stall action, as we see in the ongoing carbon emission and climate change debate. Further, in the absence of a market price for pollutant emissions, the market mechanisms described above are not able to keep supply (i.e., available sink capacity) and demand (i.e., emission of pollutants) within sustainable limits.

Despite these challenges, there are several examples where regulatory action has successfully limited emissions to rates below maximum sustainable levels. Examples include Britain's 1956 Clean Air Act, which reduced smog in London (Urbanito 1994); Amendment IV of the 1990 US Clean Air Act, which reduced acid rain resulting from $\mathrm{SO}_{2}$ (US Environmental Protection Agency 2010); and the US ban of the presumed carcinogen DDT from pesticides (US Environmental Protection Agency 1972). However, many other unsustainable practices have arisen or remain unaddressed. Perhaps the most widely cited is the emission of $\mathrm{CO}_{2}$ and other GHG relative to the biosphere's ability to assimilate them. Rockström et al. (2009) point out that the earth was ice-free until the concentration of atmospheric $\mathrm{CO}_{2}$ decreased to $450+/-100$ parts per million (ppm). To maintain the earth's current climate system, of which the polar ice caps are such a crucial component, they suggest a boundary of $350 \mathrm{ppm}$, which we have already exceeded. It is therefore not surprising that the UN Intergovernmental Panel on Climate Change (IPCC) has stated that "warming of the climate system is unequivocal" and that "most of the observed increase in global average 
temperatures since the mid-20th century is very likely due to the observed increase in anthropogenic [greenhouse gas] concentrations" (IPCC 2007).

There are numerous, more localized examples of unsustainable emission into sinks, such as the emission of air particulates in Beijing reaching nearly three times the "emergency" threshold for air quality (Associated Press 2013, January 13); similar air quality issues in Singapore, Malaysia and Indonesia (Wong 2013, June 20); waste and sewage discharge into China's Yellow River rendering over one-third of the river unusable even for agricultural and industrial purposes and less than one-sixth sufficiently clean for domestic use (Branigan 2008, November 25); and the accumulation of plastic debris throughout the world's oceans and seas (Derraik 2002). As global consumption increases and production systems ramp to satisfy this demand, we should expect such reports to become more frequent.

\section{Implications for business}

Research commissioned by the Central Intelligence Agency and conducted by the National Research Council (2012) concluded that climate crises are likely to increase in frequency and magnitude over the coming decades, disrupting regional water supplies, food markets, public health systems, and the global supply chains of strategic commodities. These risks clearly create humanitarian, geopolitical, and operational concerns related to political and social instability and the reliable availability of food, water, and raw materials. Given the interconnectedness of global markets, the uncertainties that such climate crises present for industry are extreme.

Specifically with respect to climate change, firms can face three types of risk (Hultman et al. 2010). First, firms that operate unsustainably bear regulatory, economic, and legal risks from policy makers and from NGOs that lobby firms directly. Emissions caused by deforestation provide one such example. The UN IPCC estimated in 2007 that deforestation and forest degradation contribute approximately $17 \%$ of annual global $\mathrm{CO}_{2}$ emissions. Sourcing practices for palm oil, an essential ingredient of cooking oil, soaps, and cosmetics, are frequently blamed for deforestation and destruction of animal habitats. Under pressure from NGOs backed by the IPCC's finding, Unilever accepted a moratorium on palm oil harvesting in South East Asia (Greenpeace 2009).

Second, firms launching or investing in new sustainable products and services also face regulatory risk. Policy fluctuations and uncertainty as regulators grapple with the issue of climate change can significantly alter the value of such investments. In Germany, the current debate about the design of feed-in tariffs - long-term guaranteed purchase agreements for electricity generated from renewable energy - is one example. This policy mechanism helped increase the share of renewables in Germany from 3\% in 1990 to $20 \%$ in 2011, with yearly investments peaking in 2010 at 27.9 billion EUR (BMU 2012). However, the currently negotiated redesign with significantly lower 
remuneration has led to the cancellation of planned investments in renewable energy. In general, as climate change policies are continually refined, the value of sustainability opportunities will be subject to substantial changes with the ebb and flow of policy.

Third, firms' profits and cash-flows in many sectors are directly exposed to climate instability. This set of firms is larger than one might think. Cachon et al. (2012), for example, estimate that US auto manufacturers lose an average of about $1.5 \%$ of their available capacity per year due to severe weather, results that the authors point out become more important given the threat of anthropogenic climate change. Aon estimates that there was $\$ 200$ billion in climate-catastropherelated damage in 2012, including $\$ 65$ billion from hurricane Sandy and $\$ 35$ billion from a drought in the US Midwest (Aon Benfield 2013). Given the predicted increase in the frequency and magnitude of climate crises (National Research Council 2012), we should expect these costs to grow under any business-as-usual scenario. To mitigate such costs, Kleindorfer (2009) challenges the insurance industry to become a knowledge broker in the area of climate risk, with the goal of integrating risk management solutions with sustainability strategies. Similarly, Jaffe et al. (2010) and Kleindorfer et al. (2012a) advocate multiyear property insurance as a mechanism by which individuals can reduce their financial exposure to climate change, replacing that volatility with stable insurance premiums over several years.

\section{How Can an Operations Management Lens Contribute?}

OM offers a vital sustainability perspective. At the micro-level, firms' operational decisions determine the production and distribution technologies and system design that they employ. These in turn determine how efficiently (and which) materials and energy are consumed as well as the type and intensity of waste injected into ecosystems, which aggregate to determine global source and sink consumption rates and, ultimately, the sustainability of an ecosystem with respect to human activity. Sustainable OM, therefore, potentially has an important role to play in contributing to solutions for the sustainability challenges that we currently face. However, to fulfill that potential, we must deliver on the stream's implicit promise - to generate research that enables production and distribution systems to operate more efficiently with respect to their environmental and social impact. Research that fulfills this promise must not only be rigorously executed, it must also directly or indirectly influence firm decisions and/or shape policy. Such research will satisfy at least one, and ideally both, of the following criteria: (i) it engages practitioners and/or policy makers; and (ii) it embraces the multidisciplinary nature of the sustainability challenge.

Not satisfied with a handful of paragraphs at the end of his papers to make the case for his work's managerial implications, Paul's modus operandi throughout his career was to engage with firms and policy makers to fine tune research questions and communicate results. He embraced the 
role of a management academic, and with it the scholarly duty to affect practice. Paul engaged with practice and/or policy makers in all of the streams that he was active in; engaging with postal operators around the world with Michael Crew, partnering with industry and government organizations while co-directing the Risk Management and Decision Processes Center at Wharton, and doing the same while playing an integral role in the Social Innovation Centre at INSEAD.

He created opportunities for his students and colleagues to engage with practitioners as well. When one of us brought the topic for our first dissertation paper to Paul, his response was not the expected "how do you plan to formulate the problem," rather it was "Wonderful! Now let me find some managers for you to meet with."

For sustainable OM to endure as a topic of importance and interest, it seems such an approach is required. The growing salience and magnitude of sustainability in general are not enough. Sustainable OM's value to the broader field of sustainability hinges on its micro view of firms' processes and environment-i.e., its conceptual proximity to firms' actual operations. It therefore seems that interest in Sustainable OM is likely to wane unless it ultimately delivers on this value by influencing the manner in which firms operate. Engaging directly with practitioners, policy makers, and those who will one day fill such roles (i.e., our students) is the most direct way in which to achieve that impact, which gives rise to the first criterion.

The second criterion arises because the world's challenges are often not cleanly partitioned by academic department, a fact abundantly clear in the case of sustainability where scholars from a host of disciplines contribute their research efforts. Consequently, most sustainability challenges will not be met by efforts from a single discipline, but will require interaction and collaboration across disciplines. For example, implementing a market price for carbon emissions to address climate change risks requires not only understanding how firms would adjust their OM decisions in response to a carbon market. It also requires climate science, economics, public policy, and law perspectives, to name a few. The impact that any one stream has on practice and policy relies on the degree to which it is integrated with parallel efforts in other streams. This complementarity suggests that the ability of any given sustainability stream to endure as an important field depends in part on the extent to which scholars collaborate across disciplines.

Such a multi-disciplinary approach came naturally to Paul. He not only was one of the most broadly-read academics that we have known, he also often attended other field's conferences, coauthored with scholars from other disciplines (e.g., Crew and Kleindorfer 1970, Kleindorfer and Orts 1998, and Rosenthal et al. 2006), and published in non-OM outlets (e.g., Crew and Kleindorfer 1976, Kunreuther and Kleindorfer 1980, Schulkin and Kleindorfer 1995, and Kleindorfer 2008). Such cross-pollination requires intentional effort but pays off by increasing the visibility of Sustainable OM research beyond our own circle of scholars, enhancing its potential impact. One recent example 
of such an effort is Plambeck (2012), which reviews Sustainable OM research related to climate change for the environmental economics community.

Clearly, in addition to the two criteria above, both sustainability and operations management must be at the core of Sustainable OM research. There are several avenues through which this can be achieved. Many decisions that determine a firm's sustainability impact also naturally intersect with established OM streams such as, product design, technology choice, and supply chain management. Sustainable OM considers these operational decisions with the intent of identifying opportunities and potential pitfalls related to improving firms' ecological efficiency. We briefly discuss five active themes in the field, describing how a few contributions in each address the criteria outlined above.

\section{Product design}

The concept of cradle-to-cradle (McDonough and Braungart 1998, McDonough and Braungart 2000) has been highly relevant to sustainable product design. This concept-which itself is in accordance with the notion of biomimicry (Benyus 1997) - helped popularize the notion of industrial ecology (e.g., Kneese et al. 1970), modeling industry according to nature's processes, such that output (waste) from one system becomes an input (nutrient) to another system. Two types of "nutrients" are distinguished: biological nutrients (e.g., compostable products), and technical nutrients, which refer to, for instance, a product that can be disassembled and hence reused in another product. The OM literature at the intersection of product design and sustainability focuses on such design choices. This literature informs several stakeholders: legislators with regard to setting the right incentives for green product design, manufacturers in terms of the ramifications of product design choices, and investors with respect to their valuation of green product development initiatives.

In this vein, Plambeck and Wang (2009) analyze the impact of e-waste collection alternatives on the frequency of new product introduction. They find that fee-upon-sale schemes enhance sustainability by inducing manufacturers to introduce new products less frequently but with higher quality. However, the authors find that this type of scheme does not incentivize manufacturers to engage in design for recyclability, which can be achieved through fee-upon-disposal regulation. This work therefore highlights an unexpected policy trade-off; to incentivize less frequent product introduction (and fewer units produced) versus greater recyclability. Agrawal and Ülkü (2013) study modular upgradability which is commonly recommended in the product design literature as an enabler of sustainable products by allowing single components (rather than entire units) to be upgraded and hence disposed of. However, the authors show that, for product categories such as computers, modular upgradability increases environmental impact by accelerating obsolescence. Agrawal and Ülkü (2013) integrate product design, engineering, and OM perspectives and relate 
their results to specific product categories which helps connect their findings to managerial practice. Raz et al. (2013) study firm investments to improve environmental performance in the manufacturing and in the use phases of a product's lifecycle. They show that firms should invest more in improving the environmental efficiency of manufacturing for functional products, but should invest more in improving the environmental efficiency of product use for innovative products. Ba et al. (2012) bridge the investors' and the firm's perspectives as they show, by means of an event study, that the stock-market's reaction is generally positive to green development initiatives in the automotive industry.

\section{Production technology choice}

The adoption of cleaner technologies is a necessary condition for a sustainable future. Indeed, the principal reason that the dire predictions made by Malthus (1798) have not come to pass is because technologies have thus far been developed and adopted to allow production to grow exponentially; i.e., at pace with population (Trewavas 2002). In a sustainable economy, technology adoption must achieve similar efficiency gains with respect to the reduction of toxic emissions. The sustainable technology choice literature explores such adoption. Specifically, the Sustainable OM technology choice literature studies investment in production technologies that vary across multiple dimensions, with one of the focal dimensions relating to environmental performance such as pollution intensity (the amount of waste emitted per unit of production). There is no hardand-fast delineation between technology choice research in Sustainable OM versus Environmental Economics (see Jaffe et al. 2002, and Popp et al. 2009 for reviews of the latter). However Sustainable OM typically takes a more granular view of firms' objectives and decision process (e.g., through discrete technologies and/or uncertainties pertinent to the setting).

In this stream, İşlegen and Reichelstein (2011) provide an excellent example of multi-disciplinary work that is well-connected to practice. They advise carbon policy by estimating the break-even emissions price for the adoption of Carbon Capture and Storage (CCS) technology in power generation, finding the CCS adoption threshold for natural gas to be twice that of coal-fired production (at $\$ 60$ and $\$ 30$ per ton of emissions, respectively). Based on these adoption thresholds, the authors estimate that electricity prices would increase no more than $30 \%$ as a consequence of emissions regulation. The analysis in İşlegen and Reichelstein (2011) is multi-disciplinary in that it addresses discrete technology choice, while applying costing methodology derived in the energy literature (levelized cost of electricity), and explicitly accounting for differences in US state-level power generation policy. Drake et al. (2012) analyze a firm's optimal portfolio of discrete technologies under carbon regulation, advising carbon policy by countering conventional wisdom, showing that the firm earns greater expected profit under cap-and-trade than a carbon tax due to emissions price 
uncertainty under the former and the option not to produce. ${ }^{2}$ The authors also summarize the motivating example from this research in a pedagogical case as a vehicle to communicate their principal findings to students, executives, and policy makers (Drake et al. 2010).

\section{Transportation systems}

Transportation generates over $23 \%$ of the world's carbon emissions, making it the second largest source of emissions behind power generation (European Commission 2010). Further, fleet-related expenses make up about $20 \%$ of logistics providers' total costs (Le Groupe La Poste 2012). Together, these facts point to the environmental and commercial importance of transportation, with technology choice playing a central role. Transport technology choice is distinct from production technology choice in a number of important ways: it is generally less capital-intensive to acquire increments of transport capacity; transport technologies are often concurrently available for commercial and private purchase; and transport technologies are often constrained by vehicle range and routing requirements. The environmental benefits derived from transport electrification depend on the environmental performance of the power grid it draws from. Likewise, transport electrification has been shown to enable greater investment in renewable energy through vehicle-to-grid services and other technologies that mitigate intermittency concerns associated with most renewable energy sources (Richardson 2013, and Hein et al. 2012).

Kleindorfer et al. (2012b) analyze the case of a large fleet operator, La Poste. Given the choice between conventional diesel vehicles and electric vehicles (EVs), and accounting for postal operators' Universal Service Obligation (Crew and Kleindorfer 2005), they conclude that EVs allow La Poste to significantly lower their fleet cost while also reducing their carbon foot print by about $30 \%$ due to a $75 \%$ share of nuclear power in France's energy portfolio (World Nuclear Association 2013, May). Due to the tight orchestration between the research team and La Poste's management (the Director of Mail Operations at La Poste was a co-author on the paper), this research was sufficiently well-grounded in practice to enable La Poste to commit to the purchase of 15,600 EV's in October 2011. Wang et al. (2011) provide an extension to the previous paper by allowing for uncertain vehicle demand which gives rise to a portfolio solution of vehicle technologies. The authors derive an optimal policy for investments in sustainable transport technologies, applying it to the case of Coca-Cola where the optimal fleet composition is shown to consist of nearly an even mix of diesel and hybrid electric vehicles. This optimal portfolio is demonstrated to reduce CocaCola's fleet costs by between 2 and $6 \%$ relative to a single-vehicle-type fleet while also reducing the

\footnotetext{
${ }^{2}$ Like Drake et al. (2012), İşlegen et al. (2012) independently show that variability in emissions price under cap-andtrade increases firms' expected profits relative to a carbon tax. They do so in a competitive setting without technology choice to study carbon leakage and international trade while Drake et al. (2012) do so in a non-competitive setting with discrete technology choice and endogenous capacity constraints to study technology portfolios.
} 
fleet's environmental impact. While the previous papers explore sustainable transport through the adoption of cleaner vehicle technologies, Akyol and De Koster (2013) illustrate that environmental gains can also be achieved by integrating transport planning and policy perspectives. By exploring the effect of municipal policy restricting freight delivery times, they show that coordination of such policies across urban areas can lead to environmental and financial improvements while concurrently satisfying municipality objectives.

\section{Forward supply chain}

Sustainable supply chain management extends the scope of analysis from a single firm or industry to multiple echelons of suppliers, manufacturers, distributors, and/or retailers. By its nature, this scope often reaches across organizational and national boundaries, introducing decisions and challenges such as overall supply chain design, information asymmetry, contracting and coordination, and geopolitical and regional trends. While this can add considerable complexity, it can also add vital perspective when considering sustainability since the majority of a product's ecological impact often falls beyond any single tier's organizational boundaries. For example, Matthews et al. (2008) estimate that the direct carbon emissions from an industry, on average, represent only $14 \%$ of that industry's total supply chain emissions.

Within this stream, two recent papers explore emissions allocation policies when those emissions are jointly determined by multiple products or firms. Keskin and Plambeck (2011) analyze allocation rules for emissions generated by a process that yields co-products. When one co-product is imported into an emissions-regulated region protected by a carbon tariff and the other is consumed in the (unregulated) region that it was produced, the authors find that allocating emissions to co-products based on their relative price can counter-intuitively lead to increased production and emissions. Caro et al. (2013) study a setting where a product's GHG emissions result from a supply chain's joint effort-i.e., the emissions from at least one process are determined by the efforts of multiple partners. They find that, in such settings, emissions must be over-allocated to achieve welfare-maximizing abatement efforts. Both papers advise carbon policy by providing emissions allocation guidance in settings where operational complexity blurs carbon footprint boundaries.

In work exploring supply chain information sharing related to climate change exposure and performance, Jira and Toffel (2013) empirically study the factors that contribute to suppliers' willingness to comply with buyer requests for emissions disclosure. They find compliance to be greater when suppliers belong to more profitable industries, have a greater number of buyers requesting the information, and/or are located in GHG regulated countries. Kalkanci et al. (2013) explore the effect of policy intended to improve supply chain transparency (the public disclosure of performance). They warn that government regulation requiring firms to disclose what they know 
of their supply chain's environmental and social performance can have the unintended effect of deterring the measurement of that performance. Together, these papers provide guidance on when firms are likely (and are not likely) to disclose details to their partners and to the public relating to environmental their performance.

\section{Closed-loop supply chain}

Dating back to at least the Environmental Handbook published to coincide with the first Earth Day (De Bell 1970), the environmentalists' directive has been "reduce, reuse, recycle." Research in the streams discussed above generally address sustainability through the first of these R's. In comparison, Closed-Loop Supply Chain (CLSC) research-literature focusing on product recovery and reuse - addresses the latter two R's, adding "remanufacturing" to the set. That said, it should be noted that these Sustainable OM streams are not mutually exclusive. There are contributions in the other streams noted above that intersect with the CLSC literature through a focus on reuse, remanufacturing, and or recycling (e.g., see Debo et al. 2005 for sustainable technology choice work that intersects with CLSC; and Plambeck and Wang 2009, Atasu and Subramanian 2012, and Subramanian et al. 2013 for sustainable product design work that intersects with CLSC). Souza (2012) provides a thorough tutorial and review of the closed-loop supply chain literature while Guide and Van Wassenhove (2009) describe the stream's evolution.

The exploration of Extended Producer Responsibility (EPR) - regulation whereby manufacturers are held accountable for the recovery and reuse or disposal of their products - has been an active area of CLSC research well-integrated with policy (e.g., Atasu et al. 2009, Jacobs and Subramanian 2012, Gui et al. 2013). Gui et al. (2013), for example, show that return-share methods traditionally employed by regulators to allocate recovery costs to manufacturers result in fragmented and relatively costly collection networks. The authors instead propose an alternative allocation scheme that adjusts for firms' marginal return costs and capacity contributions to the collection network. To ground their research, the authors engage practitioners-interviewing collectors, processors, transporters, and NGOs - and calibrate their model with data collected from Washington state's product recovery program. The research is also multi-disciplinary, using an economic method (collaborative game theory) to test specific policy options through a detailed operational model of a product recovery network.

Some recent CLSC research leverages perspectives from both OM and marketing, incorporating behavioral studies to ground and calibrate analytic results with consumer preferences. For example, Ovchinnikov (2011) conducts a behavioral study that indicates cannibalization of new products by remanufactured products is inverted-u-shaped in price. Using these results, he shows that (contrary to conventional wisdom) a firm should generally set a much lower price for their remanufactured 
products than the myopic price that ignores the presence of new products. Also leveraging behavioral results, Agrawal et al. (2012) show that an Original Equipment Manufacturer (OEM) reduces the perceived quality of their new products when they remanufacture their own goods. However, they show that the perceived quality of an OEM's new products increases with the presence of a third-party remanufacturer. By incorporating behavioral methods, both of these papers are able to guide the development of remanufacturing processes with insight that would likely not have come to light in the absence of such a multi-disciplinary approach.

\section{Conclusion}

Sustainability will endure as a topic of interest to a variety of stakeholders (including managers and management scholars) due to a causal chain with links likely to persist for the foreseeable future. First, growth of the principal drivers of aggregate consumption-population and per capita consumption - does not appear likely to abate. Second, evidence suggests that this growth has already led, in several instances, to consumption and pollution rates that exceed sustainable levels. Third, this unsustainable consumption of specific sources and sinks has created a set of risks, costs and opportunities that can directly impact firm profitability. All of this points to the ecological impact of industry continuing to escalate in both its salience and stakes. Consequently, sustainability in general will endure as an important and active field.

Firms' OM decisions determine the technologies that they employ and the design of their production and distribution systems, all of which play a fundamental role in determining industry's source and sink consumption. Firms' OM decisions are therefore principle contributors to anthropogenic effects on ecosystem sustainability. As a consequence, Sustainable OM is likely to endure as an active and important stream if we deliver on its implicit promise: to generate research that enables production systems to operate more efficiently with respect to their environmental and social impact. Such research must ultimately advise and impact practice and/or policy. It can do so by (i) engaging practitioners and/or policy makers; and (ii) embracing the multidisciplinary nature of the sustainability challenge. By producing research that satisfies these two criteria, we as a community maximize our ability to deliver on the stream's promise and contribute to making the quality-of-life gains delivered through industry more harmonious with the world around us. When we do that, the importance of and interest in the stream will flourish; or, as Paul was fond of saying, "we'll be cooking with gas."

\section{References}

Aflaki, S. 2013. The effect of environmental uncertainty on the tragedy of the commons. Forthcoming in Journal of Games and Economic Behavior. 
Agrawal, V. V., A. Atasu, K. van Ittersum. 2012. Remanufacturing, third-party competition and consumers' perceived value of new products. Working paper, Georgetown University McDonough School of Business.

Agrawal, V. V., S. Ülkü. 2013. The role of modular upgradability as a green design strategy. Forthcoming in Manufacturing $\mathscr{B}$ Service Operations Management.

Akyol, D. E., R. B. M. De Koster. 2013. Non-dominated time-window policies in city distribution. Production and Operations Management 22(3) 739-751.

Aon Benfield. 2013. Annual global climate and catastrophe report: Impact forecasting 2012 Retrieved from: http://thoughtleadership.aonbenfield.com/Documents/20130124_if_annual_global_climate_catastrophe_report.pdf.

Associated Press. 2013, January 13. Beijing air pollution off the charts. Retrieved from http://www.cbsnews.com/8301-202_162-57563685/beijing-air-pollution-off-the-charts/ on January 31, 2013.

Atasu, A., R. Subramanian. 2012. Extended producer responsibility for e-waste: Individual or collective producer responsibility? Production and Operations Management 21(6) 1042-1059.

Atasu, A., L. N. Van Wassenhove, M. Savary. 2009. Efficient take-back legislation. Production and Operations Management 18(3) 243258.

Ba, S., L. L. Lisic, Q Liu, J. Stallaert. 2012. Stock market reaction to green vehicle innovation. Forthcoming in Production and Operations Management.

Benyus, J. M. 1997. Biomimicry: Innovation inspired by nature. William Morrow Paperbacks, New York, N.Y., USA.

BMU. 2012. Renewable energy sources in figures. Federal Ministry for the Environment, Nature Conservation and Nuclear Safety of Germany.

Branigan, T. 2008, November 25. One-third of China's Yellow River 'unfit for drinking or agriculture'. The Guardian. Retrieved from http://www.guardian.co.uk/environment/2008/nov/25/water-china on January 26, 2013.

Cachon, G. P., S. Gallino, M. Olivares. 2012. Severe weather and automobile assembly productivity. Working paper, University of Pennsylvania.

Caro, F., C. J. Corbett, T. Tan, R. Zuidwijk. 2013. Double-counting in supply chain carbon footprinting. Forthcoming in Manufacturing 83 Service Operations Management.

Corbett, C. J., P. R. Kleindorfer. 2001a. Introduction to the special issue on environmental management and operations (part 1: Manufacturing and eco-logistics). Production and Operations Management 10(2) $107-111$.

Corbett, C. J., P. R. Kleindorfer. 2001b. Introduction to the special issue on environmental management and operations (part 2: Integrating operations and environmental management systems). Production and Operations Management 10(3) 225-227. 
Corbett, C. J., P. R. Kleindorfer. 2003. Environmental management and operations management: Introduction to the third special issue. Production and Operations Management 12(3) 287-289.

Crew, M. A., P. R. Kleindorfer. 1970. A note on peak loads and non-uniform costs. The Economic Journal $80422-423$.

Crew, M. A., P. R. Kleindorfer. 1976. Peak-load pricing with a diverse technology. Bell Journal of Economics $7208-231$.

Crew, M. A., P. R. Kleindorfer. 2005. Competition, Universal Service and the Graveyard Spiral. In: M. A. Crew and P. R. Kleindorfer (Eds.) Regulatory and Economic Challenges in the Postal and Delivery Sector. Kluwer Academic Publishers, Boston, USA.

Daly, H. 1990. Toward some operational principles of sustainable development. Ecological economics 2(1) $1-6$.

De Bell, G., ed. 1970. The Environmental Handbook Prepared for the First National Environmental Teach-in April 22, 1970. Ballantine Books, New York, USA.

Debo, L. G., L. B. Toktay, L. N. Van Wassenhove. 2005. Market segmentation and product technology selection for remanufacturable products. Management Science 51(8) 1193-1205.

Derraik, J. G. B. 2002. The pollution of the marine environment by plastic debris: a review. Marine Pollution Bulletin 44 842-852.

Drake, D. F., P. R. Kleindorfer, L. N. Van Wassenhove. 2010. Heidelbergcement: Technology choice under emissions regulation. Case 610-014-1, European Case Clearing House.

Drake, D. F., P. R. Kleindorfer, L. N. Van Wassenhove. 2012. Technology choice and capacity portfolios under emissions regulation. Working paper, Harvard Business School.

Ehrlich, P. R., J. P. Holdren. 1971. Impact of population growth. Science 171 1212-1217.

El Serafy, S. 1989. The proper calculation of income from depletable natural resources. In: Y. J. Ahmad, S. El Serafy, and E. Lutz (Eds.) Environmental accounting for sustainable development. World Bank, Washington D.C., USA, 10-18.

European Commission. 2010. EU energy in figures 2010: $\mathrm{CO}_{2}$ emissions by sector. Retrieved from http://ec.europa.eu/energy/publications/doc/statistics/ext_co2_emissions_by_sector.pdf on February 26, 2013.

European Commission. 2013. The EU Emissions Trading Scheme (EU ETS). Retrieved from http://ec.europa.eu/clima/policies/ets/index_en.htm on January 26, 2013.

footprintnetwork.org. 2013. World footprint: Do we fit on the planet? Retrieved from: http://www.footprintnetwork.org/en/index.php/GFN/page/world_footprint/ on June 11, 2013.

Global Financial Data. 2013. GFDatabase. Accessed on February 13, 2013. 
Greenpeace. 2009. Public pressure for Indonesia's forests works, ask Unilever. Retrieved from: http://www.greenpeace.org/international/en/campaigns/forests/asia-pacific/dove-palmoil-action/on February 6, 2013.

Gui, L., A. Atasu, Ö. Ergun, L. B. Toktay. 2013. Implementing extended producer responsibility legislation. Journal of Industrial Ecology 2.

Guide, V. D. R., L. N. Van Wassenhove. 2009. The evolution of closed-loop supply chain research. Operations Research 57(1) 10-18.

Hardin, G. 1968. The tragedy of the commons. Science 163 1243-1248.

Hein, R., P. R. Kleindorfer, S. Spinler. 2012. Valuation of electric vehicle batteries in vehicle-to-grid and battery-to-grid systems. Technological Forecasting 83 Social Change 79 1654-1671.

Hultman, N. E., D. M. Hassenzahl, S. Rayner. 2010. Climate risk. Annual Review of Environment and Resources 35(2010) 283-303.

İşlegen, Ö., E. L. Plambeck, T. Taylor. 2012. Variability in emissions-cost: Implications for facility location, production and trade. Working paper, Stanford Graduate School of Business.

İşlegen, Ö., S. J. Reichelstein. 2011. Carbon capture by fossil fuel power plants: An economic analysis. Management Science 57(1) 21-39.

IEA. 2012. World energy outlook - Special report — Golden rules for a golden age of gas. International Energy Agency, Paris, France.

IPCC. 2007. Climate change 2007: The physical science basis. Retrieved from: http://www.ipcc.ch/pdf/assessment-report/ar4/syr/ar4_syr.pdf on January 26, 2013.

Jacobs, B., R. Subramanian. 2012. Sharing responsibility for product recovery across the supply chain. Production and Operations Management 21(1) 85-100.

Jaffe, A., R. G. Newell, R. N. Stavins. 2002. Environmental policy and technological change. Environmental and Resource Economics 22(1) 41-69.

Jaffe, D., H. Kunreuther, E. Michel-Kerjan. 2010. Long-term property insurance. Journal of Insurance Regulation 29(7) 167-187.

Jira, C. F., M. W. Toffel. 2013. Engaging supply chains in climate change. Forthcoming in Manufacturing \& Service Operations Management.

Kalkanci, B., E. Ang, E. L. Plambeck. 2013. Measurement and improvement of social and environmental performance under voluntary versus mandatory disclosure. Working paper, Stanford Graduate School of Business.

Kerr, R. A. 2011. Peak oil production may already be here. Science 331 1510-1511.

Keskin, N., E. L. Plambeck. 2011. Greenhouse gas emissions accounting: Allocating emissions from process to co-products. Working paper, Stanford Graduate School of Business. 
Kleindorfer, P. R. 2008. Trust, Ethics and Markets. In: J. V. Ciprut (Ed.) Ethics, Politics and Democracy. MIT Press, Cambridge, USA.

Kleindorfer, P. R. 2009. Interdepency of science and risk finance in catastrophe insurance and climate change. Working paper, INSEAD.

Kleindorfer, P. R., H. Kunreuther, C. Ou-Yang. 2012a. Single-year and multi-year insurance policies in a competitive market. Journal of Risk an Uncertainty 45(1) 51-78.

Kleindorfer, P. R., A. Neboian, A. Roset, S. Spinler. 2012b. Fleet renewal with electric vehicles at La Poste. Interfaces 42(5) 465-477.

Kleindorfer, P. R., E. Orts. 1998. Informational regulation of environmental risks. Risk Analysis 18(2).

Kleindorfer, P. R., K. Singhal, L. N. Van Wassenhove. 2005. Sustainable operations management. Production and Operations Management 14(4) 482-492.

Kneese, A. V., R. U. Ayres, R. C. d'Arge, eds. 1970. Economics and the Environment: A Materials Balance Approach. The Johns Hopkins Press, London, UK.

Kunreuther, H., P. R. Kleindorfer. 1980. Guidelines for coping with natural disasters and climatic change. Journal of Environmental Policy 3(4).

Lattanzio, R. K. 2013. Canadian oil sands: Life-cycle assessments of greenhouse gas emissions. Congressional Research Service.

Le Groupe La Poste. 2012. Document de reference 2011. Rapport financier annuel.

Malthus, T. R. 1798. An essay on the principle of population, as it affects the future improvement of society: with remarks on the speculations of Mr. Godwin, Marq. Condorcet, and other writers. J. Johnson, London, UK. Published as an unabridged republication: Malthus, T. R. 2007. An Essay on the Principle of Population. Dover: Mineola, NY.

Matthews, H. S., C. T. Hendrickson, C. L. Weber. 2008. The importance of carbon footprint estimation boundaries. Environmental Science and Technology 42.

McDonough, W., M. Braungart. 1998. The next industrial revolution. The Atlantic Monthly 282(4) 82-92.

McDonough, W., M. Braungart. 2000. A world of abundance. Interfaces 30(3) 55-65.

McKibben, B. 2012. Global warming's terrifying new math. Rolling Stone [online] 2.

Meadows, D. H., D. L. Meadows, J. Renders, W. W. Behrens III. 1972. The Limits to Growth: A Report for the Club of Rome's Project on the Predicament of Mankind. Universe Books, Washington D.C., USA.

Meinshausen, M., N. Meinshausen, W. Hare, S. C. B. Raper, K. Frieler, R. Knutti, D. J. Frame, M. R. Allen. 2009. Greenhouse-gas emissions targets for limiting global warming to $2^{\circ} \mathrm{C}$. Nature 458 1158-1162.

Mining, \& Sustainable Development Project. 2002. Breaking New Ground: Mining, Minerals, and Sustainable Development: the Report of the MMSD Project. Earthscan Publications, London, UK. 
Murray, J., D. King. 2012. Oil's tipping point has passed. Nature 481 433-435.

National Research Council. 2012. Climate and Social Stress: Implications for Security Analysis. J. D. Steinbruner, P. C. Stern and J. L. Husband, Eds. The National Academies Press, Washington D.C., USA.

Ovchinnikov, A. 2011. Revenue and cost management for remanufactured products. Production and Operations Management 20(6) 824-840.

Plambeck, E., Q. Wang. 2009. Effects of e-waste regulation on new product introduction. Management Science 55(3) 333-347.

Plambeck, E. L. 2012. Reducing greenhouse gas emissions through operations and supply chain management. Energy Economics 34(Supplement 1) S64-S74.

Popp, D., R. G. Newell, A. B. Jaffe. 2009. Energy, the environment, and technological change. NBER Working Paper Series.

Raz, G., C. Druehl, V. Doctori-Blass. 2013. Design for the environment: Life-cycle approach using a newsvendor model. Forthcoming in Production and Operations Management.

Richardson, D. B. 2013. Electric vehicles and the electric grid: A review of modeling approaches, impacts, and renewable energy integration. Renewable and Sustainable Energy Reviews 19 247-254.

Rockström, J., W. Steffen, K. Noone, A. Persson, F. S. Chopin III, E. Lambin, T. M. Lenton, M. Scheffer, C. Folke, H. J. Schellnhuber, B. Nykvist, C. A. de Wit, T. Hughes, S. van der Leeuw, H. Rodhe, S. Sörlin, P. K. Snyder, R. Costanza, U. Svedin, M. Falkenmark, L. Karlberg, R. W. Corell, V. J. Fabry, J. Hansen, B. Walker, D. Liverman, K. Richardson, P. Crutzen, J. Foley. 2009. A safe operating space for humanity. Nature $461472-475$.

Rosenthal, I., P. R. Kleindorfer, M. R. Elliott. 2006. Predicting and confirming the effectiveness of systems for managing low-probability chemical process risks. Process Safety Progress 25(2).

Schulkin, J., P. R. Kleindorfer. 1995. Equity decisions: Economic developmemt and environmental prudence. Human Rights Quarterly 17(2) 382-389.

Simon, J. L. 1998. The Ultimate Resource 2. Princeton University Press, Princeton, NJ.

Souza, G. C. 2012. Closed-loop supply chains: A critical review, and future research. Forthcoming in Decision Sciences.

Subramanian, R., M. Furguson, L. B. Toktay. 2013. Remanufacturing and the component commonality decision. Production and Operations Management 22(1) 36-53.

Trewavas, A. 2002. Malthus foiled again and again. Nature 418 668-670.

UN, Department of Economic and Social Affairs, Population Division. 2011. World population prospects: The 2010 revision, volume I: Comprehensive tables. ST/ESA/SER.A/313.

UN Development Programme. 2006. Human development report 2006: Beyond scarcity: Power, poverty and the global water crisis. Retrieved from http://hdr.undp.org/en/media/HDR06-complete.pdf on February 24, 2013. 
UN Water. 2013. Water use statistics: Graphs \& maps. Retrieved from http://www.unwater.org/statistics_use.html on February 24, 2013.

Urbanito, D. 1994. London's historic "pea-soupers". EPA Journal. Retrieved from http://www.epa.gov/aboutepa/history/topics/perspect/london.html on January 10, 2013.

US Energy Information Administration. 2012. IEA and EIA: Similarities and differences in projections and approaches to energy modeling. Retrieved from http://www.eia.gov/pressroom/presentations/howard_04162012.pdf on February 24, 2013.

US Environmental Protection Agency. 1972. DDT ban takes effect. Retrieved from: http://www.epa.gov/aboutepa/history/topics/ddt/01.html on February 7, 2013.

US Environmental Protection Agency. 2010. Acid rain program benefits exceed expectations. Retrieved from: http://www.epa.gov/capandtrade/documents/benefits.pdf on February 7, 2013.

US Environmental Protection Agency. 2011. Toxics release inventory. Retrieved from: http://iaspub.epa.gov/triexplorer/tri_release.chemical on January 26, 2013.

USDA Economic Research Service. 2013. Agricultural productivity in the us. Retrieved on May 19, 2013 from http://www.ers.usda.gov/data-products/agricultural-productivity-in-the-us.aspx\#.UcSKl5xHMi8.

Wackernagel, M., L. Onisto, P. Bello, A. C. Linares, I. S. L. Falfán, J. M. García, A. I. S. Guerrero, M. G. S. Guerrero. 1999. National natural capital accounting with the ecological footprint concept. Ecological Economics 29 375-390.

WHO/UNICEF. 2009. Diarrhoea: Why children are still dying and what can be done. Retrieved from: http://www.unicef.org/health/files/Final_Diarrhoea_Report_October_2009_final.pdf on Feburary $24,2013$.

Wong, C. H. 2013, June 20. Singapore air pollution hits record. Wall Street Journal /Online Edition] Retrieved from http://blogs.wsj.com/searealtime/2013/06/20/singapore-air-pollution-indexhits-record-high/ on June 25, 2013.

World Bank. 2013. World development indicators database. Accessed on February 4, 2013.

World Nuclear Association. 2013, May. Nuclear power in france. Retrieved on June 20, 2013 from: http://www.world-nuclear.org/info/Country-Profiles/Countries-A-F/France/\#.UcOuQZxHNNo. 